\title{
The Analysis of Factors Influencing Exclusive Breastfeeding Given By Working Mothers
}

\author{
Yayuk Fatmawati' ${ }^{1}$ Biyanti Dwi Winarsih'1, Hirza Ainin Nur ${ }^{2}$
}

1 STIKES Cendekia Utama Kudus, Indonesia

2 AKPER Krida Husada Kudus, Indonesia

\section{Article Info}

\section{Article History:}

Submit July 15 th, 2020

Accepted Sept 5 th, 2020

Published Sept 30th 2020

\section{Keywords:}

Breastfeeding; Exclusive;

Working mothers

\section{INTRODUCTION}

The benefits of breast milk should be known by every mother. Breast milk is a food source for babies with essential nutrition for the health, growth, and development of infants. The content of breast milk cannot be replaced with any type of baby food since its contents, such as anti-oxidants, some vitamins, and inflammatory agents are very beneficial for babies. Moreover, breast milk is a natural food that is easily digested with a balanced nutritional composition ${ }^{1-3}$.

\section{Abstract}

Breast milk is a food source for infants with essential nutrition for their health, growth, and development. Breast milk has various benefits including preventing children from a variety of conditions that can inhibit their growth and development such as malnutrition. Malnutrition is associated with $45 \%$ of deaths and illnesses of children. Exclusive breastfeeding is considered to be able to help overcome nutritional problems such as stunting and malnutrition. A report from the Ministry of Health Republic of Indonesia in 2015 showed that $18.8 \%$ of toddlers suffer from malnutrition while $12.7 \%$ experience stunting. This study aimed to analyse factors influence breastfeeding given by working mothers. This was a quantitative descriptive study with a cross-sectional approach. The study involved 101 respondents who were working mothers of children aged 7-24 months old. The respondents were selected using questionnaire measurement tools. Data analysis used the Chi-Square test with an alpha value of 0.05 . The results show that there was no relationship between knowledge of breastfeeding and exclusive breastfeeding. However, there was a significant relationship between family support and exclusive breastfeeding. Good knowledge must be followed by a good attitude and family support, especially from the husband, so that the mother will give exclusive breastfeeding to the baby.

Corresponding author:

Biyanti Dwi Winarsih

zidanina1706@yahoo.com

South East Asia Nursing Research, Vol 2 No 3, September 2020

ISSN:2685-032X

DOI: https://doi.org/10.26714/seanr.2.3.2020.7-11 
other benefits of breast milk include preventing obesity in children, providing antibodies and emotional closeness between mother and baby to improve the psychomotor development and social abilities of the baby.

Kudus Regency is an industrial regency where there are many industries with a high number of female employees. Exclusive breastfeeding for 6 months cannot be given especially from female workers in Indonesia due to the company policy where the workers are only given $1-3$ months of maternity leave. Besides, the lack of knowledge regarding the importance of exclusive breastfeeding also influences the decision of the mothers to not give exclusive breastfeeding to their infants. is supported by ignorance about management about the condition and lack of knowledge of the importance of breastfeeding. Several studies explain that infants who do not get exclusive breastfeeding will have a lower nutritional status and cognitive function.

Malnutrition is associated with $45 \%$ of deaths and illnesses of children.5,6 Exclusive breastfeeding is considered to be able to help overcome nutritional problems such as stunting and malnutrition in toddlers, which also occur in Indonesia according to a report from the Indonesia Ministry of Health in $2015 .{ }^{7}$

Research conducted by the Millenium Challenge Account (MCA-Indonesia) in 10 provinces in 2014 showed that $55 \%$ of mothers in Indonesia did not provide exclusive breastfeeding for a variety of reasons. $43 \%$ of mothers still considered breast milk is not enough to provide the nutrition of their children. Meanwhile, if not resolved, stunting will have a broad impact on children's growth and development. Stunting is associated with suboptimal intelligence or, from an economic perspective, stunting is also associated with a decrease in productivity of up to $20 \%$. $^{7}$
This study aimed to determine the factors that influence exclusive breastfeeding in working women. These factors are analyzed to find a solution to improve the lack of exclusive breastfeeding in working women.

\section{METHODS}

This was a quantitative descriptive study with a cross-sectional approach, where the cause and effect variables that occurred in the research object were measured and collected simultaneously. This was a quantitative descriptive study with a crosssectional approach. The study involved respondents who were obtained by purposive sampling techniques using a questionnaire consisting of sociodemographic of the mothers (age, education level, and employment status), respondent's level of knowledge, and the support of their spouse. The study involved 101 respondents who were working mothers of children aged 7-24 months old and live in the working area of Ngemplak Health Center. The respondents were selected using questionnaire measurement tools. Data analysis used the Chi-Square test with an alpha value of 0.05 . The study was conducted in June 2019.

\section{RESULTS}

The result of this study explains respondents characteristics, namely working mothers with children under 2 years consist of the respondent's age, respondent's educational background, respondent's occupation and the age of the last child owned by the respondent. Table 1 shows that more than half of respondents aged between 21-30 years as many as 52 respondents (51.4\%), age $<20$ years and age $>40$ years is the age with the lowest \%age of respondents as much as 2 respondents or 2\% and age 31-40 years as many as 45 (44.6\%) respondents. The educational background of most respondents was high school education by 40 respondents or $43.6 \%$, elementary school education 38 (37.6\%) respondents 
and only $18.8 \%$ or 19 respondents had a university education. The types of work owned by the most respondents were labourers $(44.6 \%)$ or 45 respondents and the occupation with the lowest \%age was farmers namely $5(5 \%)$ respondents while self-employed and other occupations were 29 respondents or $28.7 \%$ and 13 (12.9\%), followed with work as teachers as many as 9 (8.9\%) respondents. Most children's age of respondents was 13-24 months (55.5\%) or as many as 56 respondents and aged 712 months were 45 respondents or $44.5 \%$.

Table 1

Respondents Characteristics ( $\mathrm{n}=101)$

\begin{tabular}{lcc}
\hline \multicolumn{1}{c}{ Indicators } & $\mathrm{f}$ & $\%$ \\
\hline Age & & \\
$<20$ years old & 2 & 2 \\
$21-30$ years old & 52 & 51.4 \\
$31-40$ years old & 45 & 44.6 \\
$>40$ years old & 2 & 2 \\
\hline Educational background & & \\
$\quad$ Elementary school & 38 & 37.6 \\
High School & 44 & 43.6 \\
University & 19 & 18.8 \\
\hline Occupation & & \\
Labor & 45 & 44.6 \\
Entrepreneur & 29 & 28.7 \\
Farmer & 5 & 5 \\
Teacher & 9 & 8.9 \\
Other & 13 & 12.9 \\
\hline Toddler's age & & \\
7 - 12 months old & 45 & 44.5 \\
13 - 24 months old & 56 & 55.5 \\
\hline
\end{tabular}

Table 2 is a table about exclusive breastfeeding analysis, which was obtained from 101 respondents 52 respondents $(51.5 \%)$ gave exclusive breastfeeding and $48.5 \%$ or 49 respondents did not give exclusive breastfeeding. While the respondent's knowledge about exclusive breastfeeding 96 (95\%) of respondents was well-informed and only 5 (5\%) of respondents were adequate-informed. Most family support that is owned by respondents is enough family support as many as 48 respondents or $46.5 \%, 44$ respondents or $43.5 \%$ of respondents get good family support, while a small proportion of respondents namely 9 respondents or $9 \%$ have less family support.
Table 2

Exclusive Breast Feeding Analysis ( $\mathrm{n}=101)$

\begin{tabular}{lcc}
\hline \multicolumn{1}{c}{ Indicators } & $\mathrm{f}$ & $\%$ \\
\hline Exclusive breastfeeding & & \\
$\quad$ Given & 52 & 51.5 \\
$\quad$ Not given & 49 & 48.5 \\
Knowledge of breastfeeding & & \\
$\quad$ Adequate & 5 & 5 \\
$\quad$ Good & 96 & 95 \\
Family support & & \\
$\quad$ Poor & 9 & 9 \\
$\quad$ Moderate & 48 & 46.5 \\
Good & 44 & 43.5 \\
\hline
\end{tabular}

Table 3 will explain the analysis of factors that influence exclusive breastfeeding for working mothers, where the results show that the factors that influence exclusive breastfeeding are family support with significant value. While respondents' knowledge about exclusive breastfeeding does not affect exclusive breastfeeding in working mothers with significant values.

Table 3

Influence Factors Analysis ( $\mathrm{n}=101)$

\begin{tabular}{llccc}
\hline \multirow{2}{*}{ Indicators } & \multicolumn{2}{c}{$\begin{array}{c}\text { Exclusive } \\
\text { breastfeeding }\end{array}$} & \multirow{2}{*}{$\mathrm{p}$} \\
\cline { 3 - 4 } & & Given & $\begin{array}{c}\text { Not } \\
\text { given }\end{array}$ & \\
\hline Knowledge of & Adequate & $40 \%$ & $60 \%$ & \multirow{2}{*}{0.672} \\
breastfeeding & Good & $52.1 \%$ & 47.9 & \\
\hline \multirow{2}{*}{ Family } & Poor & $22.2 \%$ & $77.8 \%$ & \\
support & Moderate & $37.5 \%$ & $62.5 \%$ & 0.001 \\
\hline
\end{tabular}

\section{DISCUSSION}

The results show that most of the respondent $(52.1 \%)$ with good knowledge of breastfeeding gave exclusive breastfeeding. The Chi-Square analysis results obtained a P-Value of 0.672 which was higher than $\alpha=0.005$, meaning there was no significant relationship between the knowledge of breastfeeding with exclusive breastfeeding.

The finding is in line with previous research where the results showed that there was no influence of knowledge of breastfeeding and the mothers' behaviour of giving exclusive breastfeeding in Padalangan village, 
Banyumanik District, Semarang with a Pvalue of $0.300 .^{8}$

Mother's behaviour in exclusive breastfeeding is influenced by knowledge and is supported by a good attitude. This is consistent with Green's theory that knowledge will form good behaviour if it is based on a good attitude and selfawareness.

Another study also obtained similar results where there was no relationship between knowledge and exclusive breastfeeding of mothers in the community health centre in Sebapai, Pemengkat District, Sambas Regency, with a P-value of $0.054 .{ }^{9}$

Other factors that influence exclusive breastfeeding are occupation and mother's age. In this study, most working mothers who have babies aged 12-24 months are labourers (44.6\%) aged 21-30 years old. This is in line with the research that found the age of the child and mother influence the exclusive breastfeeding in the legal Amazon and Northeast, Brazil. ${ }^{10}$

The results show that the majority of respondents who gave exclusive breastfeeding $(72.2 \%)$ had good family support. The Chi-Square test results obtained a p-value of 0.001 , which means that there was a significant relationship between family support and exclusive breastfeeding.

Previous research explains that most mothers who gave exclusive breastfeeding had good family, superior, and coworker supports, with the \%age reached $75.5 \%$, $65.7 \%$, and $68.8 \%$, respectively. Their study found that factors that influence the exclusive breastfeeding of working mothers are age, knowledge, attitude, availability of facilities, as well as support from family, superiors, and coworkers. ${ }^{11}$

Another study conducted obtained similar results where the majority of mothers who gave exclusive breastfeeding (75.4\%) had good family support with a P-value of $0.000 .^{12}$

Family support, especially from the husband, and community support for nursing mothers include providing advice and space for mothers to breastfeed quietly. Lack of family support can cause mothers to be less motivated in breastfeeding and switch to infant formula or other complementary feedings. ${ }^{13}$

Another research conducted found that there was a significant relationship between family support and exclusive breastfeeding with a p-value of $0.003 .^{14}$

The form of husband support to a breastfeeding mother includes motivating and accompanying the mother while breastfeeding, giving praise, taking care of the baby, and looking for information on breastfeeding. These will make the wife motivated and enthusiastic about breastfeeding. ${ }^{15}$

Another research conducted in 2013 found that there is a relationship between the support of closest people with exclusive breastfeeding in the working area of Tuladenggi community health centre in Telaga Biru Sub-district with a p-value of $0.016 .{ }^{16}$

\section{CONCLUSION}

There was no significant relationship between the knowledge of breastfeeding and the exclusive breastfeeding given by mothers working. There was a significant relationship between the family support and the exclusive breastfeeding given by mothers.

\section{ACKNOWLEDGMENTS}

The researcher would like to say thank you to all respondents who participated in this research. 


\section{CONFLICTS OF INTEREST}

Neither of the authors has any conflicts of interest that would bias the findings presented here.

\section{REFERENCES}

1. Bobak, Lowdermilk J. Buku Ajar Keperawatan Maternitas. 6th ed. Jakarta: EGC, 2010.

2. Prakoso H. Pengguanaan ASI dan Rawatgabung dalam Ilmu Kebidanan. Jakarta: Yayasan Bina Pustaka Sarwono Prawirohardjo, 2002.

3. Masoara S. Manfaat ASI Untuk Bayi, Ibu Dan Keluarga. Program Manajemen Laktasi. Jakarta: Perkumpulan Perinatologi Indonesia, 2003.

4. Alimoradi F et all. An overview of importance of breastfeeding. J Compr Pediatr; 2.

5. Giri M. K. W. Hubungan pemberian ASI eksklusif dengan status gizi balita usia 6-24 bulan di Kampung Kajanan. J sains dan Teknol; 2.

6. Novita L. et all. Perbandingan Fungsi Fognitif Bayi Usia 6 Bulan yang Mendapat dan yang Tidak Mendapat ASI Eksklusif. Sari Pediatr; 6.

7. Dinas Kesehatan. Profil kesehatan provinsi jawa tengah tahun 2012. Semarang: Dinas Kesehatan Provinsi Jawa Tengah, 2014.

8. Rahmawati M. D. Faktor-faktor yang mempengaruhi pemberian ASI eksklusif pada ibu menyusui di kelurahan Pedalangan kecamatan Banyumanik kota Semarang. J KesMaDasKa; 1.
9. Fricilia dan Agustiansyah. Faktor - faktor yang Mempengaruhi Ibu dalam Pemberian ASI Eksklusif kepada Bayi di Puskesmas Sebangkau Kecamatan Kecamatan Pemengkat Kabupaten Sambas. Pontianak Nutr J; 1.

10. Neves A.C.M.D. et all. Factors associated with exclusive breastfeeding in the Legal Amazon and Northeast regions, Brazil, 2010. Rev Nutr 2014; 1: 81-95.

11. Septiani B dan K. Faktor - Faktor yang Berhubungan dengan Pemberian ASI Eksklusif oleh Ibu Menyusui yang Bekerja sebagai Tenaga Kesehatan. J Ilmu Kesehat 2017; 2: 159-174.

12. Sohimah dan Lestari. Analisis Faktor yang mempengaruhi pemberian ASI Eksklusif di Wilayah Kerja Puskesmas Cilacap Tengah I Kabupaten Cilacap Tahun 2017. JIm Kebidanan 2017; 8: 125-137.

13. Prasetyono. Dwi Sunar. Buku pintar ASI eksklusif (pengalaman, praktik dan kemanfaatan-kemanfaatannya). Yogyakarta: Diva Press, 2012.

14. Anggorowati. Hubungan Antara Dukungan Keluarga dengan Pemberian ASI Eksklusif Pada Bayi. J Keperawatan Matern; 1.

15. Yuliarti N. Keajaiban ASI- Makanan Terbaik Untuk Kecerdasan dan Kelincahan si Kecil. Yogyakarta, 2010.

16. Hilala Agnes. Faktor - Faktor yang Berhubungan dengan Pemberian ASI Eksklusif di Wilayah Kerja Puskesmas Tuladenggi Kecamatan Telaga Biru. J S1 Keperawatan UNG. 